\title{
From Rights to Justice: Women of Color Changing the Face of US Reproductive Rights Organizing
}

Luna

Follow this and additional works at: https://scholarlycommons.law.case.edu/swb

Part of the Human Rights Law Commons, and the Social and Behavioral Sciences Commons

\section{Recommended Citation}

Luna. 2009. "From Rights to Justice: Women of Color Changing the Face of US Reproductive Rights Organizing." Societies Without Borders 4 (3): 343-365.

Available at: https://scholarlycommons.law.case.edu/swb/vol4/iss3/4 


\title{
From Rights to Justice: Women of Color Changing the Face of US Reproductive Rights Organizing
}

\author{
Zakiya Luna \\ University of Michigan, Ann Arbor
}

\begin{abstract}
The history of government racism is part of the explanation of the limited contemporary use of human rights in the US. This history poses a challenge to mainstream organizations' ability to organize using human rights, yet some contemporary organizations embrace these concepts that are in full use within international settings. This article focuses on the emergent reproductive justice movement, a women of color-based social movement which complicates the narrow focus on protection of legislation such as Roe v. Wade by integrating human rights analysis of domestic social problems. In doing so, this paper expands understanding of uses of human rights in the US and illustrates how race and gender identities contribute to social movement organizing around reproduction.
\end{abstract}

Keywords

social movements, women's rights, women of color, reproduction, identity

\section{Introduction}

During the 2008 presidential election, an independent funding organization released a television advertisement criticizing Democratic nominee Senator Barack Obama's refusal to sign the Illinois Born Alive Infants Protection Act. ${ }^{1}$ In the television ad, images of babies from different racial backgrounds fill the screen. Then a young woman comes onto the screen and asks the viewer "Can you imagine not giving babies their basic human rights, no matter how they entered our world?"

\footnotetext{
1) Supporters of the Act argued that it ensured fetuses from unsuccessful abortions were defined as people and provided medical treatment. Opponents argued it was redundant with federal legislation and a backdoor way to erode Roe v. Wade.

2) CNN Ticker 2008. 
In both this contemporary example, and historically, the United States (US) government has acted ambivalent, if not hostile, toward the idea of human rights instead focusing on narrower civil rights. Additionally, US social movement organizations not explicitly engaged in international human rights activities have resisted integrating human rights into their work. ${ }^{3}$ Yet, the aforementioned presidential election advertisement provides but one recent example of how "human rights" has entered the mainstream US discourse. Activists perceive that the concept of human rights can mobilize US audiences on domestic issues. Gaining wider interest in organizing around human rights, however, remains a challenge for organizers. This is primarily because many people outside (and even within) the respective US social movements believe that human rights are what people need in other countries.

Reproductive and sexual health rights within the US context remain an area of rights that even recent reflections on human rights in the US have not explored adequately. ${ }^{4}$ This article focuses on the reproductive justice movement, focusing on a unique US organization, SisterSong Women of Color Reproductive Collective (SisterSong), has utilized a human rights framework in their work. Specifically, this project assesses how SisterSong moves beyond the narrower focus on civil and political rights (dominant in US social movements) to emphasize other aspects of human rights when organizing for women's sexual and reproductive rights. First, this paper provides a brief history of human rights within the US and assessment of (mis)use of the phrase "human rights" by both state and social movement actors. This is followed by an analysis of documents from these women of color-focused social movement organization integrating human rights. I end with conclusions on what this analysis means for scholars. This paper expands understanding of uses of human rights in the US and illustrates how race and gender influence human rights-based organizing around reproduction.

\section{History of Human Rights in the US}

At their most basic level, human rights "are held by all human beings, irrespective of any rights or duties that individual may (or may not) have

3) Mertus 2007.

4) Blau and Moncada 2006; Merry 2006; Blau, Brunsma, Moncada, and Zimmer 2008. 
as citizens, members of families, workers, or parts of any public or private organization or association." 5 People in the US have exposure to human rights; many just do not know how human rights apply in a US context because of the popular notion that the US is well off in comparison to other countries. Even some authors implicitly assume the strength of the current legal system reduces the need for an emphasis on human rights. For instance, legal scholar Michael McCann emphasizes the need for "appreciating the increasing power of human rights norms around the world, within polities and transnational or international arenas where authoritative legal institutions are often underdeveloped or contested." 6 While McCann is partially correct, he focuses on the importance of human rights to other countries, assuming that legal mobilization utilizing human rights would not be necessary in US (i.e., a "developed" context with authoritative legal institutions).

According to the Universal Declaration of Human Rights (UDHR), everyone has the same human rights irrespective of any social statuses. Nevertheless, supporters of human rights point out that some human rights are privileged over others. In many countries, "Civil and political rights are viewed therefore as inherent, universal and justifiable, while social and economic rights are viewed as evolving gradually as a matter of social policy rather than fundamental justice." This "first generation" of human rights are most supported by the US government.

After World War II, multiple nation-states debated how to ensure that the atrocities of the Holocaust would not be repeated, and proposed developing the United Nations (UN). The National Association for the Advancement of Colored People (NAACP) was particularly active in attempting to develop a program of human rights that would transform the system of racial oppression in the United States that had been the standard practice for centuries. ${ }^{8}$ Members of the NAACP worked to have their voices heard in this developing UN and acted as consultants along with other non-governmental organization. The US representatives, however, resisted inclusion of proposals on racial equality as they wanted to maintain the current social order that placed African Americas at the bottom, at least, avoid having it publicly scrutinized. A deeper commitment to

\footnotetext{
5) Donnelly 2007, p. 21.

6) McCann 1996, p. 2.6 .

7) Kerr 1993, p. 5.

8) Anderson 2003.
} 
human rights would pose a major threat to maintaining a social hierarchy that benefited political elites.

Ultimately, historian Carol Anderson concludes that "the loss of real American involvement in the development of international human rights protocols and the pervasive notion that there was something un-American and foreign, if not totally communistic, about human rights converged to severely constrict the agenda for real black equality." In a racially hostile, and sometimes deadly, climate, groups such as the NAACP had to fight strenuously for civil rights even with the Constitutional claim of liberty for all. Thus, full human rights extending beyond civil rights seemed an almost impossible fantasy.

Political scientist Zoelle suggests the tension between civil rights and more expansive human rights results from the initial goal of civil rights legislation being primarily to protect African Americans and women from active discrimination. This important difference is that "A human right implies that any system of government is unacceptable if it denies the full expression of the natural, inalienable rights of human beings. On the other hand, civil rights are merely adjustments to a systemic structure that is otherwise entirely acceptable." ${ }^{10}$ Cold-War politics kept the NAACP and others during that era from being able to mobilize effectively using human rights. However, even with this dismal history, the idea of the systemic justice, as would be necessary with achievement of human rights, provides an ideal toward which some contemporary activists work.

\section{Contemporary Uses of Human Rights in the US}

US social movement organizations not explicitly engaged in international human rights have been reticent to integrate human-rights discourse into their work. This is not surprising as the US state, while active in shaping of UDHR, has also been critiqued for refusing to acknowledge its own human rights violations. US policy makers are not against human rights but rather they define human rights differently than the international community does, which leads to different actions even if the words are the same. In her research on US policy makers' views on human rights, scholar Julie Mertus found they were often "referring to a short list of American values, to be

9) Anderson 2003, p. 254.

10) Zoelle 2000, p. 15. 
projected and applied to others in line with American national interests." 11 These values emphasize civil and political rights, the foundation of Western concepts of democracy.

The US government's focus on first generation human rights has an impact on state and social movement practices. For many people living within the US, human rights appear to be a problem only outside of the US and when "human rights" is used in the United States, it is often used as a synonym for civil rights protected US law. For example, 22 US states have state agencies with "human rights" in their title (e.g., New York State Division of Human Rights). These agencies focus on discrimination in public areas (such as employment and housing) based on statuses protected in the Civil Rights Act of 1964 such as race and sex with some also addressing sexuality or single-parent status. Thus, these agencies do not broadly address human rights violation as understood internationally but instead, substitute civil rights for human rights. Additionally, few US organizations engage with human-rights discourse in the domestic arena, even if they have human rights in their title. One example is Human Rights Campaign, which is dedicated to equality for gay, lesbian, bisexual, and transgender people. Its website makes no mention of the origin of the phrase "human rights," provides no explanation of the Universal Declaration of Human Rights or discussion of human rights organizing around LGBT rights at the international level. While the work that it and other organizations do helps build a more just society, by not linking their work to a history of human rights activism, they miss opportunities to educate their members, an opportunity of which SisterSong takes advantage as will be analyzed in the next section.

Substitution of "civil rights" for "human rights" in everyday practice leads to the common perception in the US that human rights violations happen to political prisoners in China or to women in Africa - not to citizens in the US. Despite these misconceptions, human rights they retain moral authority due to their status as the one framework many states and activists throughout the world engage with, even if they do so with reservation. ${ }^{12}$ Thus, we can attribute an increasing use of human rights framing in the US to anthropologist Merry's observation from her case studies that "human rights ideas are appealing because they provide a radically

11) Mertus 2004, p. 2.

12) Bunch 1990. 
different frame for thinking about the relations of power and inequality in society." 13 Because the radical discourse of civil rights is no longer as radical, activists are considering tools to take their work to another level.

Sociologists Judith Blau and Alberto Moncada point out that the narrower civil and political rights that the US government supports are not to be dismissed; but even those rights are not protected to their fullest by our government - even when compared to some of the nations people in the US most readily perceive as violating human rights. ${ }^{14}$ While the laws enacted through a civil rights approach have been instrumental in reducing racism and sexism in the US, they have not done enough to change the conditions that allow for racism and sexism.

A common critique of human rights is that they are a Eurocentric construct forced upon Third World nations by the US and other powerful nations. This can be the case when human rights are used to justify state aggression such as the war in Afghanistan (where women were "liberated" from the Taliban by US) or when defined to mean democratization through acceptance of structural adjustment policies. Still, Merry, whose research on local activists opposing violence using human rights language includes one example based in the US, has a more optimistic conclusion that recognizes the agency of everyday people: "when grassroots people use the human rights framework, it is appropriated rather than imposed.... Activists translate rights claims into frameworks that are relevant to the life situations of grassroots people." 15 Just as activists do with narrower civil-rights claims, they take up human rights ideas only to the degree they prove useful to them. Activists are not passive bystanders duped into accepting an incompatible model - they parse out the ideas that resonate most within their own social context. The resonance of the language of human rights is partially determined by identities of activists and the issue around which they are organizing as is demonstrated in my later analysis.

\section{Sexuality and Reproduction as Sites for Human Rights}

Recent activism by feminists has focused on the idea of "women's rights as human rights." In this debate, multiple authors have challenged the

13) Merry 2006, p. 180.

14) Blau and Moncada 2006, p. 52.

15) Merry 2006, p. 216. 
private/public distinction. ${ }^{16}$ They argue that placing the issues women face in the realm of the private sphere leads to them not being taken seriously as "real" human rights violations that result from explicit state action (such as imprisonment due to political views). Therefore, son preference, employment discrimination, domestic abuse and other violation occur with the state's tacit permission. ${ }^{17}$ Additionally, by attributing these violations to culture, states absolve themselves of their responsibility in stopping these acts. Bunch argues, "Sex discrimination kills women daily. When combined with race, class, and other forms of oppression, it constitutes a deadly denial of women's right to life and liberty on a large scale throughout the world." ${ }^{8}$ These scholars go so far as to question whether women are even human when they continue to face human rights violations prohibited by the UDHR in $1948 .{ }^{19}$

Reproduction is an important area of inquiry when analyzing human rights debates because "the physical territory of this political struggle over what constitutes women's human rights is women's bodies." ${ }^{20}$ Sociologist Bryan Turner proposes that debates over these rights emerge due to changing economic conditions in which women have led to women gaining more economic and social power. Changing social contracts have provided most people the right to choose partners without family and state interference but this freedom has led to heated contests around rights. ${ }^{21}$ As people become more aware of their vulnerability, social groups attempt to control some of the most personal aspects of people's lives. What scholars such as Turner do not address is that, historically, women of racial minority backgrounds have had to endure disproportionate consequences resulting from these attempts at control. Thus, efforts by these groups to gain human rights may not look like those of people who face oppression based on only one oppressed status.

Historically, intersectional analyses offered by women of color have challenged feminist theory and activism that assumed that the shared oppression of women should take precedence over organizing against racism,

\footnotetext{
16) Binion 1995; Bunch 1990; Cook 1993; Kerr 1993a.

17) Kerr 1993b.

18) Bunch 1990, p. 489.

19) MacKinnon 2006.

20) Bunch 1990, p. 491.

21) Turner 2006, p. 70.
} 
classism, homophobia, or these multiple oppressions simultaneously. ${ }^{22}$ This resulted in conflicts within the women's movement of the "second wave" of feminism, but also set the stage for a shift toward more holistic analyses of oppression and varied organizational approaches such as that of SisterSong's. Thus, part of the appeal of human rights for marginalized groups is the opportunity these ideas pose to restructure society while also allowing for recognition of multiple identities.

\section{SisterSong: Working at the intersection of social movements}

SisterSong's network of organizations frames the concern around women's control of their bodies in terms of needing reproductive justice rather than only reproductive rights. SisterSong explicitly integrates human rights discourse into its literature. Its work represents a shift for women advocating for control of their bodies, from a narrower focus on legal access and individual choice (the focus of mainstream reproductive women's organization such the National Organization for Women), to a broader analysis of structural constraints on agency. SisterSong explains: "The intersectional theory of Reproductive Justice is described as the complete physical, mental, spiritual, political, social, environmental and economic well-being of women and girls, based on the full achievement and protection of women's human rights. ${ }^{23}$ Of note is that achievement of reproductive justice is imagined as happening specifically through attaining human rights. The lack of widespread human rights law in the US should result in fewer opportunities to mobilize human rights discourse, which would result in weakened belief in the utility of human rights. This way of framing reproduction resonates and is leading to changes in reproductive rights organizing nationwide, despite activists having fewer common cultural references on which to draw to construct an effective frame. Thus, SisterSong offers an ideal case to extend scholarly understandings about social movements engaging with human rights discourses.

Earlier social movements such as the Black Power movement have been criticized for their sexist tendencies. In addition, among social movements that explicitly address sexism and gender, such as the "second wave" of

22) Combahee River Collective 1983.

23) Ross 2006, p. 1. 
feminism, criticisms of unexamined racism emerged. ${ }^{24}$ Women of color continued to work in these movements, but also founded autonomous organizations that sought to address both racism and sexism. These autonomous organizations provided a foundation for multilayered analysis of how multiple oppressions result in different experiences for different groups of women. In addition to tension around race, class differences were another site of tension, as demonstrated by analysis emphasized by two different groups organizing around reproductive rights middle-classsupported National Abortion Rights Action League (now NARAL ProChoice America) and the more diverse Committee for Abortion Rights and Against Sterilization Abuse (CARASA). NARAL Pro-Choice America focused on access to abortion while some of their literature on poor women criticized their fertility by focusing on the "social costs of uncontrolled childbearing." 25 In contrast, the more diverse CARASA focused on abortion rights but vocally challenged the forced sterilization of poor women, which denied them the right to have children.

Decades before the creation of SisterSong, poor women, who were disproportionately of racial minority groups, launched a critique of the mainstream reproductive rights framework because it did not address how these women lacked control over their reproduction. Abortion, as a legal right, was (and is) emphasized by mainstream groups as a matter of individual choice whereas alternative groups focus on a range of reproductive rights that were dependent on structural support that human rights emphasize. Many of the autonomous reproduction-related organizations, like CARASA, no longer exist. Their successors, however, are now moving into the relatively unexpected direction of integrating human rights.

\section{Data and Methods}

Influenced by activism for gender equality, civil rights and international human rights, SisterSong was founded in 1997 with 16 organizations and currently has over 80 member and affiliate organizations and hundreds of individual members. These organizations are primarily based in the contiguous US, although a few are based in Puerto Rico and Hawaii or have

\footnotetext{
24) Bambara 1970; Combahee River Collective 1983; Roth 2004.

25) Ferree and Hess 1985, p. 88.
} 
links with international organizations. The founding organizations were four organizations from each of the original "mini-communities" of SisterSong: Asian/Pacific Islander, Black/African American, Latina and Native American/Indigenous. Organizations included larger organizations such as the National Asian Women's Health Organization to local organizations such as Project Azuka Women's AIDS Project, which served African-American women. Later, SisterSong added a Middle Eastern/Arab American mini-community, a caucus for white allies and a caucus for men of color. These caucuses exist to support SisterSong's primary focus on organizing around women of color's reproductive health concerns. The collective is composed of member organizations and individual members from across the country. To join, members agree to SisterSong's nine Principles of Unity, which stresses coalition work with other organizations and protection of various types of rights (including reproductive and sexual rights) as part of human rights.

Currently, there are six people who staff the national office in Atlanta, including the National Coordinator, Loretta Ross, who used to direct the National Center for Human Rights Education. Working Committees address areas such as organizing, mobilizing, research and publicity. SisterSong holds a national membership meeting or conference every year with hundreds of attendees, some of whom attend with the aid of scholarships, which are provided with the aid of thousands of dollars in grants to SisterSong. Speakers include members from local organizations as well as nationally known experts such as former Attorney General Jocelyn Elders. SisterSong staff also provide trainings (e.g. "What is reproductive justice?") and consult with member organizations on how to incorporate reproductive justice into their projects. Funding comes from foundations, membership fees, and organizations including mainstream organization such as Planned Parenthood, which has provided sponsorship for conference.

This article draws on publicly available documents and interviews. Since 2004, SisterSong has published a newsletter (Collective Voices) on an annual or bi-annual basis. Current circulation stands at 18,000. The newsletter highlights multiple types of stories: news articles provide statistics on relevant topics, personal narratives reflect on involvement with member organizations or reproductive justice activism, and others explain the history of the collective. Some pieces are written by people identified as SisterSong staff or committee members, although many list the author as a member or remain unidentified. 
The analysis focuses on the first eight newsletters distributed 2004-2007, which averaged 21 pages. Focusing on the formal documents explicitly produced for consumption by members and potential supporters allows an assessment of how activists construct the discourse of civil rights and human rights. I augment my analysis with data I have collected over two years through interviewing SisterSong members, archival research, and conducting participant observation at local and national events (a national conference, a workshop at the US Social Forum, a Reproductive Justice 101 training, and a national membership meeting).

\section{Results and Discussion}

\section{Choosing Human Rights}

With civil rights and women's rights being dominant and somewhat successful separate movements, trying to combine these efforts into one movement that then integrates human rights is a challenge both financially and strategically. Nonprofits, which often rely on foundation funding, have to overcome misconceptions to convince funding bodies these ideas are valid. With a rights discourse based on Constitutional values dominant in the US, providing funding to groups challenging the limits of that model would seem risky if not counter to the mission of the funders. Reflecting on its history of confronting resistance by funding agencies, a SisterSong founder writes,

[A] decade ago the concept of funding human rights work in the United States was novel to the foundation world because human rights meant only international funding, while 'civil rights' was stretched to cover human rights abuses in the U.S... a sizable number of foundations are raising more than $\$ 10$ million to support U.S.focused human rights work, an idea scorned a mere decade ago. ${ }^{26}$

This quote educates members less familiar with the history of human rights in the US on how human rights was a stigmatized discourse even in the early 1990s. Human rights was not unknown but, instead, scorned and therefore perceived negatively.

26) Diallo 2005, p. 11 
One interviewee, who oversees part of the legal program for a reproductive rights organization that often argues Supreme Court cases, noted the disjuncture between different groups:

... The two groups can really work together... the rights-based groups have a strong understanding of how to get things going within the legal system, and I think that what we need to be more creative about is expanding that to include international bodies and human rights... using human rights mechanisms (Katherine Grainger, Center for Reproductive Rights, 2007 Personal Interview).

While there are benefits to a human-rights analysis, there are potential strategic drawbacks due to its marginalized position in the United States. An article in SisterSong's newsletter from a linked organization illuminates the logic of focusing on human rights despite a hostile climate faced by reproductive justice activists:

\footnotetext{
A human rights framework both speaks to the need to demand rights, not ask for privileges and the need to connect with other women and struggles worldwide through using a universal, internationally agreed upon framework.... Limitations on ratification and when the U.S. government fails to ratify human rights treaties (as it has failed to do so on most treaties) prevent individuals in the United States from securing these human rights through legal claims. Nonetheless, as activists we continue to use the human rights framework as our standard which should hold governments accountable. ${ }^{27}$
}

Since members may be unfamiliar with human rights, stories such as this provide a context for the concept (international recognition), how the US government limits human rights within the US (failure to ratify treaties) and, most importantly, why SisterSong continues to use this framework despite what appears to be a futile battle. Part of what the organization does is educate its members on human rights, which, for many readers, may be a foreign idea. Alternatively, they may only think of human rights as a synonym for civil rights, which is how the US government has traditionally engaged with human rights. Additionally, these rights are to be understood as entitlements rather than privileges. Pieces such as this emphasize how human rights fits into the work of activism in the US and perhaps just as importantly, women's activism throughout the world. Recognition of the validity of international rights provides the ability to make

27) Levi 2006, p. 10. 
rights claims, but US social movements are still able to engage with discourse and deploy it for their own purposes, namely holding up an ideal toward which to work.

\section{Educating on Global-Local Rights}

SisterSong wants people to gain rights, but recognizes that traditional legislation can work against marginalized members of society. In a front-page story about how reproductive justice relates to immigrant rights, SisterSong notes that the heightened legal consciousness of opposing groups can have an effect on communities to which some members of the wider membership belong:

It is critical to understand that, as this legislation is pending approval, the amount of public debate that is created by these proposals also trigger different types of behaviors from different groups of people... US citizens who work in institutions such as schools, hospitals, and banks among others, feel empowered to request immigration documents inappropriately, without guidelines and without legal authorization. This was the case immediately after California voters authorized the passage of Proposition 187 in 1994 (a law that denied social services, health care and public education to illegal immigrants and was subsequently struck down by the federal court). ${ }^{28}$

SisterSong cautions members to recognize how, even if there is no legal authority, opposition may attempt to overstep legal boundaries. Scholarly literature on legal consciousness assumes such consciousness is a positive development, but here SisterSong shows negative impacts of a group using this consciousness to deprive other people of their human rights.

Another important point within this specific example is that even though citizens who oppose immigration felt empowered, they did not have legal standing to take these actions. Also important is that a court stepped in to limit the effect of legislation. This shows that the organization recognizes that local defeats to its movement in the legal system are part of a larger process in which success can happen at other levels of that same legal system.

Because this organization recognizes that women are part of multiple communities, it overtly links reproduction to multiple movements rather than having it be only a "women's issue." Some ways SisterSong does this are by having member organizations write updates on their own work

\footnotetext{
28) Jimenez 2006, p. 1, emphasis added.
} 
that might, at first glance, seem unrelated but connect with reproduction. Additionally, in each issue of the collective's newsletter, there are updates on women's reproductive rights in other countries. Still, since the organization is based in the US, one of its most important activities is to educate readers on how to apply a human rights lens to multiple problems within the US.

The following excerpt provides an example of how SisterSong's inclusion of human rights in its analysis of reproduction allows it to critically examine additional social issues than are found in material from organization focused on legal access to abortion services. A piece that looks at Hurricane Katrina as a feminist issue also connects Katrina to global problems. Specifically, one column links what many people still see as a natural disaster to the conflict between Palestine and Israel:

\footnotetext{
We also witnessed the incredible violations of the human rights of the Katrina survivors. Not only was their right to survive threatened by the painfully slow response of local, state and federal governments, but their right to stay united as families, their right to adequate and safe shelter, their right to social services, their right to accurate information, their right to health care and freedom from violence. All of these are human rights violations but the one that brings the Middle East most forcefully to mind is the violation of the right to return to one's home. For those of us with shortterm memories, keep in mind that the Supreme Court ruled this year that governments have expanded powers of eminent domain that may be used to prevent some survivors from ever returning to their communities as land is turned over to corporate developers. ${ }^{29}$
}

The quote above demonstrates how the organization takes familiar contemporary issues (such as Katrina) links them to specific articles of human rights documents, and relates them to the US legal system's role in the violation of human rights of its own citizens. At first glance, Katrina appears unrelated to the Palestinian-Israeli conflict, but this piece highlights the role of powerful governments in both the US and Israel to underscore the similarities between a "natural" situation and a situation that people understand as a product of human relations. Since the government's handling of Katrina continued to frustrate people (particularly of color), readers would be able to empathize with people across the world with whom they would otherwise feel disconnected.

29) Ross 2005, p. 2. 
Even if rights are of limited use, activists recognize the mobilizing potential of rights and the positive consequences of having a right recognized. To encourage a broader view, the organization highlights human rights documents to explain gaps in the US legal system. Starting with the title, "Reproductive Rights are Human Rights," one piece is clearly linking reproductive rights to international human rights. Then it discusses the US' position on multiple UN treaties:

Presently there is an important set of treaties the United States has failed to ratify which include the Convention on the Elimination of All Forms of Discrimination Against Women (better known as the Women's Human Rights Treaty or CEDAW), and the Convention on Violence Against Women. Since the United States has not ratified either of these treaties, an important goal of the U.S. reproductive justice movement should be to pressure Congress to ratify these treaties, bringing the United States into compliance with the rest of the industrialized world. ${ }^{30}$

Despite the limits of the US' rights system, SisterSong encourages its readers to pressure Congress, which is embedded within the traditional rights system that often produces the problems against which members fight (e.g., prison policies or punitive welfare laws that disproportionately impact women of color). Activists who recognize the complexity and limits of gaining rights retain hope for, and work toward, rights. Since members understand themselves as specifically engaged in a social justice project, they have to focus on shifting the institutions that make up our society (including the legal system that confers rights). They do not foresee a problem with rights even though the current legal system is flawed. Despite egregious violations of their dignity, both individually and collectively, these activists retain a belief in the ability to rectify past wrongs through using some aspects of legal institutions (e.g. courts, formal complaint processes) as they challenge the nation within which that system sits.

\section{Intersecting Identities: Beyond Race or Gender}

Overall, SisterSong engages rights as a concept that mobilizes people but believes that rights are ultimately important for marginalized groups. However, codification of rights into law is not the only concern. The group was partially founded because of members' frustration with the mainstream pro-choice movement that operates assuming protecting Roe $v$.

\footnotetext{
30) SisterSong 2005, p. 17, emphasis added.
} 
Wade should be the movement's principal concern. The problem with doing so is that focusing on this one piece of legislation can ignore how some policies, that disproportionately impact minority women (such as welfare reform), are about reproduction if examined through a broader human-rights lens. Thus, SisterSong knows about the role of laws and courts in affecting women's lives, but understands the limits of achieving narrow rights.

As previously noted, laws can shape identities and shift community relationships. Merry observes that "grassroots individuals take on human rights discourse through a double subjectivity as rights-bearers and injured kinsmen and survivors. There is not a merging and a blending, but two somewhat distinct sets of ideas and meanings that coexist." ${ }^{31}$ Multiple writings by women of color activists document how, in previous social movements, they felt pressured to choose a racial or gender community for which to seek justice. ${ }^{32}$ Keeping in mind the need to gain rights for multiple groups, but recognizing that it is these very groups that have "injured" members by insisting they only address one identity, SisterSong has found a workable solution in human rights. It describes connections between the types of rights for which human rights provide:

Reproductive Justice stresses both individuality and group rights. We all have the same human rights, but may need different things to achieve them based on our intersectional location in life - our race, class, gender, sexual orientation and immigration status. The ability of a woman to determine her reproductive destiny is directly tied to conditions in her community. The emphasis is on individuality without sacrificing collective or group identity. As with the human rights framework, it does not grant privileges to some at the expense of others. ${ }^{33}$

Emphasizing the "intersectional location in life" is also where SisterSong is doing something different from organizations that only emphasize the legal right to abortion. SisterSong emphasizes links between oppressions that affect women who need protection from the injustices, but consider these women in relation to groups that need protection.

31) Merry 2006, p. 181.

32) One often-cited text that discusses these tensions around belonging to multiple (identity) communities is Moraga and Anzaldúa's 1981 anthology This Bridge Called my Back: Radical Writings from of Women of Color.

33) Shen 2006, p. 3, emphasis added. 
SisterSong's emphasis on US communities linked to a global community beyond the US poses a challenge to women's movement activists who largely rely on ideas of individual autonomy when discussing women's rights. Here, the article's author observes that the US women's movement is critiqued for having narrow focus that does not benefit all women, thus human rights brings the possibility of building a "true" women's movement in which all women are included. One article, describing SisterSong's impact on a coalition of mainstream pro-choice organizers, explains the organization's approach:

By promoting the more inclusive human rights framework in reproductive justice organizing, SisterSong also helps the mainstream movement recognize the limits of the "choice" rhetoric, and truly build a movement to transform women's lives. This human rights-based framework is based on the early recognition among women of color organizers that we have the right to control our own bodies simply because we are human, and as social justice activists we have the obligation to ensure that those rights be protected. ${ }^{34}$

This excerpt demonstrates recognition of the importance of the rights gained by the "second wave" of feminism, but also the limits of solely focusing on the legal right to abortion. As Mark Tushnet and others discuss, rights framed in such individualistic terms do not reflect the complex interrelationships between groups. A critique of choice does just that by pointing out that a right to abortion does not change the reasons why many women get abortion, why some women's reproduction is encouraged and others discouraged, or the other rights women do not have that could make accessing this right easier - a right to economic stability; for example.

Abortion is one example of a right for which a social movement fought (and continues to) across multiple realms to maintain its legal status. As embattled as the right to abortion is, groups fight for and against its existence, buttressed by the knowledge they are fighting for or against something that exists in practice and on the legal books, unlike a more idealistic or esoteric concept such as economic justice. Multiple authors in support of rights discuss how these rights are linked to concrete policy gain and legislation. Yet, SisterSong activists recognize the limits to such gains:

34) SisterSong 2004, p. 12. 
[E]ven with Roe on the books, many women currently have limited, if any access to abortion services. The majority of poor and low-income women in the United States are denied access for a variety of reasons including abortion funding bans, bans on the provision of abortion services by government health care facilities, a shortage of abortion providers, and parental involvement laws. ${ }^{35}$

Cleary, being "on the books" is not enough for a law to be effective as the state may end up violated or curtailing it, even thought the state is ostensibly supposed to protect the human right of bodily integrity. Therefore, social movements have to fight for more than protection of existing laws. They have to encourage new ways of thinking that challenge current popular discourses.

An example of how SisterSong's embrace of human rights translates into grassroots organizing is the 2004 March for Women's Lives. The 2004 March initially focused on established ideas around which the National Organization for (and other major co-sponsors) had organized previous marches, namely access to abortion. NOW noted that its 1989 and 1992 "mass marches forced the issue of abortion rights into the forefront of political debate." ${ }^{36}$ After planning for the 2004 March began, a representative from NOW approached SisterSong members at a membership meeting to seek its endorsement. After the plenary session at which members debated the proposal, SisterSong members agreed to endorse the March but with certain stipulations, the first of which was to change the name of the March to reflect their concerns:

The March for Freedom of Choice was not a big enough thing for what we're talking about. Because I'd talked about [how] abortion or not to abort is not how women of color organize, because we feel that not only do we have to fight for the right to have a child, but we have to fight for the right to parent the children that we have.... So, the March for Freedom of Choice wasn't working as a title. ${ }^{37}$

The original March co-sponsors complied with the request and changed the name to the March for Women's Lives. Ross' comment demonstrates that the abortion rights/reproductive choice frame the March organizers were using to mobilize support for the protest did not resonate with Sis-

\footnotetext{
35) Shen 2006, p. 1.

36) National Organization for Women "History of Marches and Mass Action," emphasis added.

37) Global Feminisms Project 2006.
} 
terSong members because it was experientially incommensurate. While abortion was a concern, another part of members' experiences not felt by middle-class white women was that the media has continually represented their choices to become mothers as irresponsible and pathological, as seen in debates around welfare reform and other controversial issues. Even though abortion and choice remained focal points, later material produced for the March began to highlight social justice and the variety of issues around which different groups supporting the March worked. For SisterSong, this meant engagement with the concept of "reproductive justice," which focuses on achievement of human rights.

Weeks later, the first email sent from the NOW listserve that gave updates on the March announced the name was changed

To convey the sense of urgency before us and to explain in no uncertain terms that this March is about reproductive justice and freedom; access to reproductive health services, and family planning, which includes the right to practice birth control and the right to have children and determine one's family formation. ${ }^{38}$

Subsequent messages emphasized diversity of coalition support (including the NAACP) and the many ways that the march went beyond protection of the landmark Roe legislation. Organizers emphasized social justice and the linkages between identities and access to justice. After SisterSong joined the coalition, NOW's publicity material reflected a shift in framing, which was the result of SisterSong bringing in an analysis that considered race, gender and class within a context of human rights.

\section{Conclusion}

As civil rights operate in the US, they are limited because they do not require protection in the areas that other citizens do not have legal rights. In addition, those rights can be on the books but not achieved in practice. For example, all racial minorities have the same legal right to vote as whites and can sue a state if they are kept from exercising this right. Yet, since whites do not have economic stability protected (or even mentioned) in the Constitution, minorities cannot claim they are being denied their economic rights due to their racial identity because no one of any race has right

38) National Organization for Women "March News." 
to those rights. In the cases of the women with less class and/or racial privilege, achievement of specific rights around reproduction cannot be achieved until other human rights (such as economic rights) are achieved. They argue these concerns have not been taken up by the pro-choice movement fighting for reproductive rights, but are matters of reproductive justice when analyzed through a human rights lens. Immigration is not a traditional "women's issue" if gender is the only lens to analyze this contentious issue. Yet, it becomes a concern for reproductive justice advocates who consider how the specific social location and experience of immigrant (women) leads to particular experiences of violation of their reproductive rights that goes beyond inability to access abortion.

Examples such as these may fall outside the line of vision of many activists and scholars, but deeper analysis can contribute to our growing understanding of how the language of human rights is deployed in different local settings. This explains why an organization like SisterSong, which is focused on a long-term strategy of organizing a new movement for reproductive justice rather than specific legislative gains, could still perceive going against mainstream movement convention as a logical move. Because the rights for which SisterSong advocates do not currently exist within the US legal system, it advocates for a new system.

Problems with relying on the state for protection notwithstanding, rights codified into law remain conceptually and practically important for people, including the activists working to increase them. Evidence of flaws in the Constitutionally-based rights regime surrounds us daily; and eventually, even if adopted in full, we may find that human rights may not fare better in the US context. Yet, doing away with rights (as some suggest) cannot address the concrete problems oppressed groups face on a day-today basis. Thus, rights will retain their inspirational quality, but activists will continue to find ways to ensure individuals and states begin to take human rights seriously, creating the revolution for which earlier activists could only begin to hope.

Emphasizing the importance of human rights for achieving social justice in the US is not all-or-nothing for activists. In the case of SisterSong, the organization acknowledges the previous gains achieved through the narrower civil rights approaches of other movements, but also integrates a human rights analysis while balancing the rhetoric that both individual and group identities are in need of protection. This rectifies the limits of earlier movements that focused on racial justice at the expense of women 
on color's gender identities or that focused on gender at the expense of women of color's racial identities. To do this, the organization must also educate its members (and coalition collaborates who work in various movements) about those limitations and the relevance of human rights. Doing so moves the larger social movement sector toward creating the conditions of possibility that may allow for progress in human rights standards within the US.

To advance our understanding of social movements for human rights, we have to consider the multiple ways they operationalize human rights and how limits of other analyses encourage this embrace. Finally, we would be wise to avoid the same mistakes that these activists seek to avoid namely a singular focus on identity or group status that does not resonate with the lived complexity of multifaceted identities.

\section{Acknowledgements}

The author would like to thank the editors and anonymous reviewers for their thorough comments on this paper. The author also thanks Margaret R. Somers, Megan Gilster, Valenta Kabo and G3SG workgroup (Laura Hirshfield, David Hutson, Emily Kazyak, Katherine Luke, Carla Pfeffer, Kristen Scherrer) for their comments on earlier drafts of this paper.

\section{References}

Anderson, Carol 2003, Eyes Off the Prize: African Americans, the United Nations, and the Struggle for Human Rights, 1944-1955, Cambridge, UK; New York: Cambridge University Press.

Bambara, Toni C. 1970, The Black Woman: An Anthology, New York: New American Library.

Binion, Gayle 1995, 'Human rights: A feminist perspective' Human Rights Quarterly 17, (3): 509-26.

Blau, Judith R., et al. 2008, The Leading Rogue State: The United States and Human Rights, Boulder, CO: Paradigm Publishers.

Blau, Judith R., and Moncada, Alberto 2006, Justice in the United States: human rights and the U.S. constitution, Lanham: Rowman \& Littlefield Publishers.

Bunch, Charlotte. 1990. 'Women's Rights as Human Rights: Toward a Re-vision of Human Rights'. Human Rights Quarterly 12, (4) (Nov.): 486-98.

CNN Ticker Producer Alexander Mooney. Http://politicalticker.blogs.cnn.com/2008/09/ 16/obamas-abortion-record-under-fire-in-latest-independent-ad/. [cited September 
12 2008]. Available from http://politicalticker.blogs.cnn.com/2008/09/16/obamasabortion-record-under-fire-in-latest-independent-ad/.

Combahee River Collective 1983, 'Combahee River Collective Statement', In Home Girls: A black feminist anthology, Barbara Smith (ed.), pp. 272-282. New York: Kitchen Table: Women of Color Press.

Cook, Rebecca 1993, 'Gaining Redress Within a Human Rights Framework', In Ours by Right: Women's rights as human rights, Joanna Kerr (ed.), 13-15. London: Zed Books.

Diallo, Dazon D. 2005, 'Surviving Grant Writing with a Smile', Collective Voices, 1, no. 3:11.

Donnelly, Jack 2007. International Human Rights. Dilemmas in world politics. 3rd ed. Boulder, Colo.: Westview Press.

Ferree, Myra Marx, Beth B. Hess, and Irwin Taylor Sanders 1985, Controversy and Coalition: The New Feminist Movement. Boston: Twayne Publishers.

Global Feminisms Project 2006. 'Loretta Ross interviewed by Zakiya Luna', Institute for Research on Women and Gender, http://www.umich.edu/ -glblfem/en/us.html.

Jimenez, Laura 2006, 'Ningún ser humano es illegal: Immigration Reform, Human Rights and Reproductive Justice', Collective Voices, 2, no. 5:1-2.

Kerr, Joanna 1993a, 'The Context and The Goal' In Ours by right: Women's rights as human rights, 3-9. London: Zed Books.

Kerr, Joanna 1993b. Ours by Right: Women's rights as human rights. London; Zed Books

Levi, Robin 2006, 'Making the Silent Heard and the Invisible Visible', Collective Voices, 2, no. 5:10-12 and 13 .

McCann, Michael 2006, 'Law and Social Movements: Contemporary Perspectives', Annual Review of Law and Social Science, 2, 2.1-2.22.

Merry, Sally E. 2006, Human Rights and Gender Violence: Translating International Law into Local Justice, Chicago: University of Chicago Press.

Mertus, Julie 2007, 'The Rejection of Human Rights Framings: The Case of LGBT Advocacy in the US', Human Rights Quarterly 29, (4): 1036-64.

Mertus, Julie 2004. Bait and Switch: Human rights and U.S. foreign policy. Global horizons series. New York: Routledge.

Moraga, Cherrie, and Anzaldua, Gloria 1981, This Bridge Called My Back: Writings by Radical Women of Color, Watertown, MA: Persephone Press.

National Organization for Women. 'History of Marches and Mass Actions' http (accessed 6 July 2007).

National Organization for Women, 2003, 'March news-131 Days Until The March for Women's Lives!', December 16, http://www.now.org/lists/march-news/msg00000.html (accessed 6 July 2007).

Okin, Susan Moller. 1998. 'Feminism, Women's Human Rights, and Cultural Differences'. Hypatia 12, (2): 32-52.

Ross, Loretta 2006, 'Understanding Reproductive Justice' online http://www.sistersong. net/publications_and_articles/Understanding_RJ.pdf (accessed 27 July 2007).

Ross, Loretta 2005, 'A Feminist Perspective on Katrina', Collective Voices, 1, no. 3:1-4.

Roth, Benita 2004, Separate Roads to Feminism: Black, Chicana, and Whitefeministmovements in America's Second Wave, Cambridge, UK; New York: Cambridge University Press.

Shen, Evelyn 2006, 'Reproductive Justice: Towards a Comprehensive Movement', Collective Voices, 1, no. 4:1-3. 
SisterSong Women of Color Reproductive Health Collective 2005, 'Reproductive Rights are Human Rights', Collective Voices, 1, no. 3:16-17.

SisterSong Women of Color Reproductive Health Collective, 'Collective Voices', online http://www.sistersong.net/newspaper.html (accessed 27 July 2007).

Turner, Bryan S. 2006, Vulnerability and Human Rights, University Park, PA.: Pennsylvania State University Press.

Zoelle, Diana Grace 2000, Globalizing Concern for Women's Human Rights: The Failure of The American Model. New York: St. Martin's Press. 
Copyright of Societies Without Borders is the property of Brill Academic Publishers and its content may not be copied or emailed to multiple sites or posted to a listserv without the copyright holder's express written permission. However, users may print, download, or email articles for individual use. 